\title{
Pengasuhan Permissive Orang Tua dan Kenakalan pada Remaja
}

Fifin Dwi Purwaningtyas

Fakultas Psikologi, Universitas Wijaya Putra Surabaya

DOI: http://doi.org/10.29080/jpp.v11i1.337

\begin{abstract}
Juvenile delinquency is a social disorder that become a global problem, including in Indonesia. This research aims to study a correlation between permissive parenting and juvenile delinquency. Having quantitative correlational design, this research used purposive sampling technique. There are 70 high school students in Surabaya involved as a subject of this study. Data was analyzed using Spearman correlation. The results showed a significant correlation between permissive parenting and juvenile delinquency among High School students in Surabaya. A number of other parenting style can be a variable for futher research to see the tendency of delinquency. .
\end{abstract}

Keywords: Permissive parenting, Juvenile delinquency, Senior high school students

\begin{abstract}
Abstrak : Kenakalan pada remaja merupakan gangguan sosial yang menjadi masalah global termasuk di Indonesia. Penelitian ini melihat bagaimana hubungan pola asuh permissive orang tua dengan perilaku kenakalan pada remaja. Desain penelitian yang digunakan adalah kuantitatif korelasional dengan purposive teknik sampling. Sebanyak 70 orang siswa SMU di Surabaya menjadi subjek pada penelitian ini. Analisis data menggunakan korelasi spearman. Hasil penelitian menunjukkan ada hubungan yang signifikan antara pengasuhan permissive orangtua dengan perilaku kenakalan remaja di SMU Surabaya. Sejumlah model pola asuh lainnya dapat menjadi variable yang menarik untuk melihat kecenderungan kenakalan pada remaja.
\end{abstract}

Kata kunci: Pengasuhan permissive, Kenakalan pada remaja, Siswa SMU

\section{Pendahuluan}

Kenakalan pada remaja merupakan perilaku menyimpang yang mengarah pada tindakan melanggar peraturan yang diakibatkan oleh ketidakmampuan remaja dalam menjalankan tugas perkembangan. Kenakalan pada remaja juga dianggap sebagai salah satu bentuk gangguan kesehatan mental pada komunitas, yang secara langsung atau tidak langsung dapat mempengaruhi tingkat kesehatan mental masyarakat. Perkelahian, konsumsi narkoba, pergaulan bebas dan kebut-kebutan merupakan contoh kenakalan pada remaja yang berpotensi menyebabkan cedera dan bahkan kematian. Adapun dampak 
jangka panjang dapat merugikan masa depan para remaja (Anjaswarni, Nursalam, Widati, \& Yusuf, 2019).

Ada dua bentuk kenakalan yang dilakukan remaja yaitu kenakalan biasa dan kenakalan yang melanggar hukum. Contoh kasus kenakalan biasa adalah berbohong, membolos sekolah, meninggalkan rumah tanpa izin, keluyuran, memiliki dan membawa benda tajam, bergaul dengan teman yang memberi pengaruh buruk, berpesta pora, membaca buku-buku cabul, turut dalam pelacuran atau melacurkan diri, berpakaian tidak pantas dan minum minuman keras. Adapun kenakalan yang sifatnya masuk dalam pelanggaran hukum meliputi berjudi, mencuri, mencopet, menjambret, merampas, penggelapan barang, penipuan dan pemalsuan, menjual gambar-gambar porno dan filmfilm porno, pemerkosaan, pemalsuan uang, melakukan perbuatan yang merugikan orang lain, pembunuhan dan pengguguran kandungan (Mulyono, 2005).

Seperti yang dirasakan beberapa tahun ini, dengan berkembangnya jaman ke arah modern, kenakalan remaja sudah mulai meningkat dan bergeser, bukan hanya sekedar kenakalan biasa-biasa saja yang sering dilakukan oleh para remaja, akan tetapi kenakalan remaja saat ini sudah pada tindakan kriminalitas. Seperti yang dikatakan para pengamat bahwa ada pergeseran kualitas kenakalan yang dilakukan remaja. Dikatakan pula bahwa kenakalan remaja yang menjurus kriminalitas ini, dipengaruhi oleh minuman keras dan narkoba, selain itu di picu oleh pergaulan bebas dengan teman sebayanya bahkan bergaul dengan orang dewasa yang tidak punya aturan hidup, bebas seenaknya dalam bertindak maupun perlakuannya, yang tidak mengindahkan aturan ataupun norma serta nilai-nilai yang berlaku di masyarakat maupun di lingkungan sekolahnya.

Kenakalan itu selalu mempunyai konotasi serangan kejahatan, keganasan dan pelanggaran terhadap norma-norma sosial dan hukum yang dilakukan oleh anak-anak muda di bawah usia 22 tahun. Menurut Kartono (2006) kasus kenakalan paling banyak dialami remaja berusia dibawah 21 tahun, dan angka tertinggi kenakalan remaja terdapat pada usia 15-19 tahun. Kenakalan remaja adalah perilaku yang dapat menyakiti atau merugikan dirinya sendiri atau orang lain dengan melanggar norma-norma hukum, agama, kelompok, sosial seperti penyalahgunaan obat-obatan terlarang dan membolos.

Menurut Dryfoon yang dikutip (Muhammad \& Muhammad, 2006) kenakalan remaja mengacu pada suatu rentang yang luas, dari tingkah laku yang tidak diterima secara sosial. Sikap yang berlebihan di sekolah sampai pelanggaran status seperti melarikan diri dan pencurian sebagai contoh tindakan kriminal adalah bentuk kenakalan yang sering terlihat pada remaja. Jika sudah masuk ke ranah hukum, ada pembedaan antara pelanggaran indeks dan pelanggaran status. Pelanggaran indeks (index offenses) adalah tindakan kriminal yang dilakukan oleh remaja maupun orang dewasa, seperti perampokan, tindak penyerangan, pemerkosaan, pembunuhan. Adapun pelanggaran status (status offenses) merupakan tindakan yang tidak seserius pelanggaran indeks, seperti melarikan diri, membolos, minum minuman keras dibawah usia yang diperbolehkan, hubungan seks bebas dan anak yang tidak dapat dikendalikan. Tindakan ini dilakukan remaja di bawah usia tertentu yang membuat mereka dapat digolongkan sebagai pelaku pelanggaran remaja.

Tidak berbeda dengan yang dikatakan Sudarsono, (2012), bahwa kenakalan remaja sebagai kejahatan anak dapat diinterpretasikan berdampak negatif secara psikologis terhadap anak yang menjadi pelakunya, apalagi jika sebutan tersebut secara langsung menjadi semacam trade mark. Selanjutnya Sudarsono, (2012) menyebutkan dari beberapa kajian dan perumusan psikolog Dr. Fuad Hasan dan Drs. Bimo Walgito, menyatakan bahwa arti kenakalan nampak ada pergeseran mengenai kualitas subyek, yaitu dari kualitas anak menjadi remaja/anak remaja. Dalam pengertian lebih luas tentang kenakalan remaja ialah perbuatan/ kejahatan/pelanggaran yang dilakukan oleh anak remaja yang bersifat melawan hukum, anti sosial, anti susila, dan menyalahi norma-norma agama. 
Menurut Kartono (2006), remaja nakal itu mempunyai karakteristik umum yang sangat berbeda dengan remaja yang tidak nakal. Perbedaan itu mencakup perbedaan struktur intelektual, perbedaan fisik dan psikis, serta perbedaan kepribadian. Pada umumnya inteligensi mereka tidak berbeda dengan inteligensi remaja yang normal, namun jelas terdapat fungsi-fungsi kognitif khusus yang berbeda. Remaja nakal biasanya justru mendapatkan nilai lebih tinggi untuk tugas-tugas prestasi daripada nilai untuk keterampilan verbal (tes Wechsler). Mereka kurang toleran terhadap hal-hal yang ambigius, kurang mampu memperhitungkan tingkah laku orang lain, tidak menghargai pribadi lain dan menganggap orang lain sebagai cerminan dari diri sendiri. Perbedaan fisik dan psikis remaja yang nakal sering dianggap lebih "idiot secara moral" dan memiliki perbedaan ciri karakteristik yang jasmaniah sejak lahir jika dibandingkan dengan remaja normal. Bentuk tubuh mereka lebih kekar, berotot, kuat, dan pada umumnya bersikap lebih agresif. Hasil penelitian juga menunjukkan ditemukannya fungsi fisiologis dan neurologis yang khas pada remaja nakal ini, yaitu kurang bereaksi terhadap stimulus kesakitan dan menunjukkan ketidakmatangan jasmaniah atau anomali perkembangan tertentu. Perbedaan terakhir adalah ciri karakteristik individual dimana remaja yang nakal mempunyai sifat kepribadian khusus yang menyimpang.

Kenakalan pada remaja tidak sepenuhnya berasal dari individu untuk melakukan suatu tindakan yang negatif, namun faktor eksternal seperti keluarga juga ikut mempengaruhi. Keluarga seharusnya memberikan dasar pembentukan tingkah laku, watak, moral, dan pendidikan pada anak. Berhasil atau tidaknya peran orang tua dalam mendidik anaknya terlihat ketika seorang anak dalam lingkungan masyarakat. Namun saat ini ketidaksiapan orangtua dalam membina anak-anaknya sering dianggap sebagai pemicu terjadinya masalah sosial seperti kenakalan pada remaja. Orangtua dinilai terlalu memanjakan dan memberikan perhatian yang berlebihan (Kartono, 2006).

Menurut Santrock (2011) pola asuh memberikan pengaruh mikrosistem terhadap perkembangan anak. Pola asuh merupakan serangkaian interaksi yang intensif dimana orangtua berperan dalam mengarahkan anak untuk memiliki masa depan yang baik (Euis, 2004). Anak yang mendapatkan pola asuh yang baik dari orangtua menghasilkan anak yang memiliki kepribadian yang hangat, perhatian, berjiwa sosial yang memahami mana yang baik dan mana yang buruk. Berdasarkan data KPAI pada tahun 2017, salah satu penyebab terjadinya kasus kriminalitas anak dan remaja karena lemahnya peran orangtua. Pola asuh asuh yang salah menyebabkan remaja melakukan kenakalan dan lebih menentang orangtua bahkan menjadi remaja yang nakal, karena secara psikologi, remaja cenderung untuk resisten dengan segala peraturan yang membatasi kebebasannya (Sharma, \& Yadava, 2011).

Proboningrum (2001) mengemukakan empat dimensi dalam pola asuh yaitu kendali orang tua, kejelasan komunikasi orang tua dengan anak, tuntutan kedewasaan, dan kasih sayang. Kendali orang tua terkait dengan segala perilaku yang merujuk pada upaya orang tua dalam menerapkan kedisiplinan pada anak sesuai dengan patokan tingkah laku yang sudah dibuat sebelumnya. Kejelasan komunikasi orang tua dengan anak merujuk pada kesadaran orang tua untuk mendengarkan atau menampung pendapat, keinginan atau keluhan anak, dan juga kesadaran orang tua dalam memberikan hukuman kepada anak bila diperlukan. Adapun tuntutan kedewasaan lebih menekankan pada dukungan prestasi, sosial, dan emosi dari orang tua terhadap anak. Kasih sayang adalah kehangatan dan keterlibatan orang tua dalam upaya memperhatikan kesejahteraan dan kebahagiaan anak.

Menurut Allen dan Olson (2001) ada empat bentuk pola asuh yaitu demokratis (democratic), otoriter (authoritarian), permisif (permissive), dan penolakan (rejecting). Orang tua dengan pola asuh demokratis membuat peraturan serta harapan yang jelas dan mendiskusikan hal tersebut dengan anak-anak mereka. Secara umum, pola asuh demokratis membentuk anak-anak yang memiliki rasa percaya diri, bersifat periang, dan 
berorientasi pada prestasi. Selain itu pola asuh ini juga dihubungkan dengan rendahnya tekanan psikologis, tingginya harga diri, rendahnya tingkat penggunaan obat-obatan terlarang, dan rendahnya perilaku kenakalan pada remaja. Dalam pola asuh otoriter orang tua menetapkan peraturan serta harapan-harapan yang kaku dan itu diterapkan juga secara kaku pada anak-anak. Sebaliknya pola asuh permisif memberikan kebebasan kepada anak, tidak terlalu memberi bimbingan dan kontrol, kurang perhatian, dan kendali sepenuhnya ada pada anak untuk berbuat sesuka hatinya.

Anak-anak yang dibesarkan dengan pola asuh permisif dinilai lebih ekstrim dalam kemampuan untuk menyesuaikan diri, memiliki lebih banyak masalah perilaku, dan rendahnya prestasi akademis. Orang tua yang permisif tidak memiliki aturan untuk pada remaja sehingga mereka dapat melakukan apa yang diinginkan. Pola asuh permisif memanjakan anak-anak sehingga itu bisa berbahaya bagi anak yang sedang berkembang (Wittenborn, 2002). Penelitian Sunaryanti, (2016) menunjukkan hasil yang signifikan pada hubungan antara pola asuh permisif orangtua dengan kenakalan pada remaja. Pada pola asuh permisif, orang tua memberikan kebebasan yang sebebas-bebasnya kepada anak. Dengan kata lain, pola asuh permisif memberikan kebebasan yang tinggi pada anak. Sebenarnya jika kebebasan yang diberikan dapat digunakan oleh anak secara bertanggung jawab, maka itu akan membuat mereka menjadi individu yang mandiri, kreatif, inisiatif, dan mampu mewujudkan aktualisasinya.

Dampak negatif lainnya yang ditimbulkan dari penerapan pola asuh permisif adalah dapat menjadikan anak kurang disiplin dengan aturan-aturan sosial yang berlaku. Penelitian Isnasari (2014) menunjukkan bahwa semakin permisif pola asuh orang tua maka semakin tinggi tingkat kenakalan yang terjadi pada remaja. Prihatin (2014) melihat bagaimana pengaruh teman sebaya dan pola asuh orang tua terhadap perilaku mengkonsumsi minuman keras. Hasil penelitiannya menggambarkan bahwa remaja pria yang mempunyai pola asuh permisif lebih sering mengkonsumsi minuman keras. Tidak adanya kontrol dari orang tua membuat tingkat kenakalan pada remaja menjadi tinggi.

Orang tua yang menerapkan pola asuh permisif akan menghasilkan anak yang tidak mengenal aturan dan norma serta tidak memiliki rasa tanggung jawab. Remaja yang nakal seringkali berasal dari keluarga dimana orangtua jarang memantau anak-anak mereka, memberi sedikit dukungan dan mendisiplinkan mereka secara tidak efektif (Sarwono, 2011). Selain itu Hurlock (2014) menambahkan bahwa semakin orang tua memanjakan anaknya maka akan membuat anak tidak memiliki disiplin dan cenderung tidak hormat kepada yang lebih tua. Pada akhirnya, anak tidak akan belajar mengenai aturan, tidak terbiasa mengenal tanggung jawab dan kedisiplinan, tumbuh menjadi sosok yang mudah menyerah, dan akan mengalami kenakalan.

Berdasarkan hasil wawancara dan data observasi pada siswa SMU yang ada Surabaya, mereka sering membolos pada saat jam sekolah. Informasi guru BK juga mengatakan bahwa siswa yang nakal diperkirakan sekitar 45\%. Adapun kenakalan yang biasa dilakukan siswa adalah merokok, membolos, memakai baju sekolah yang ketat, dan datang terlambat. Ada juga hasil pandangan dari siswa yang mengatakan memang tidak ada pengawasan dari orang tua mereka. "Saya sering datang terlambat karena pulang malam. Orang tua tidak melarang karena bekerja di luar kota. Ketika mereka pergi saya diberikan uang saku yang banyak dan itulah saya pergunakan untuk macam-macam."

Informasi dari pihak sekolah juga menambahkan bahwa sebagian besar siswa yang melakukan pelanggaran memiliki permasalahan dalam keluarganya. Mayoritas siswa di sekolah itu berasal dari keluarga menengah ke atas dan hampir sebagian besar kedua orangtuanya bekerja sehingga orangtua hanya sedikit meluangkan waktu untuk bertemu anaknya. Selain itu tidak sedikit orangtua cenderung hanya memenuhi kebutuhan materi saja, apapun yang diinginkan anak semua dituruti. Mereka memberi kebebasan penuh kepada anak tanpa adanya larangan dan pengawasan. Beberapa siswa juga berasal dari keluarga broken home, dimana siswa tinggal bersama ibu tiri, ayah tiri atau saudaranya. 
Latar belakang tersebut menjadi dasar bagi peneliti untuk melihat hubungan antara pola pengasuhan permissive orang tua terhadap kenakalan pada remaja.

\section{Metode Penelitian}

Penelitian ini mengunakan desain kuantitatif korelasional yang bertujuan menguji ada tidaknya hubungan antara pengasuhan permissive dengan kenakalan pada remaja. Teknik analisa data yang digunakan adalah uji korelasi Spearman Rank. Penelitian ini melibatkan 70 remaja yang bersekolah di SMU Surabaya dengan rentang usia antara 14-17 tahun. Instrumen penelitian yang digunakan adalah kuesioner persepsi siswa terhadap pengasuhan permissive dan kuesioner kenakalan pada remaja. Kuesioner pola asuh permissive disusun berdasarkan teori pola asuh permissive dari Baumrind (2013) yang dikembangkan kembali oleh Proboningrum, (2001) sedangkan kuesioner kenakalan pada remaja disusun berdasarkan teori kenakalan pada remaja dari Jensen (Sarwono, 2011).

\section{Hasil Penelitian}

Hasil analisis korelasi Spearman Rank menunjukkan angka sig.(2-tailed) sebesar 0,004 . Nilai signifikansi lebih kecil daripada batas kritis $\alpha=0,05$, sehingga dapat dikatakan ada hubungan antara kedua variable. Dengan kata lain ada hubungan yang signifikan antara pengasuhan permissive orangtua dengan kenakalan pada remaja. Nilai koefisien korelasi sebesar 0,610 menunjukkan korelasi positif dalam arti semakin tinggi pola asuh permisif orangtua maka semakin tinggi pula kenakalan yang terjadi pada remaja.

Tabel 1

Hasil Analsis Uji Korelasi Spearman Rank

\begin{tabular}{|c|c|c|c|c|}
\hline & & & $\begin{array}{c}\text { Rank of pola } \\
\text { asuh } \\
\text { permisif }\end{array}$ & $\begin{array}{c}\text { Rank of } \\
\text { kenakalan } \\
\text { pada remaja }\end{array}$ \\
\hline \multirow[t]{6}{*}{ Spearman's rho } & $\begin{array}{l}\text { Rank of pola asuh } \\
\text { permisif }\end{array}$ & $\begin{array}{l}\text { Correlation } \\
\text { Coefficient }\end{array}$ & 1.000 & .610 \\
\hline & & Sig. (2-tailed) & . & .004 \\
\hline & & $\mathrm{N}$ & 70 & 70 \\
\hline & $\begin{array}{c}\text { Rank of kenakalan } \\
\text { pada remaja }\end{array}$ & $\begin{array}{l}\text { Correlation } \\
\text { Coefficient }\end{array}$ & .610 & 1.000 \\
\hline & & Sig. (2-tailed) & .004 & \\
\hline & & $\mathrm{N}$ & 70 & 70 \\
\hline
\end{tabular}

\section{Pembahasan}

Hasil Penelitian menunjukkan bahwa ada hubungan antara pengasuhan permissive orang tua dan kenakalan pada remaja. Pola asuh permisif dilihat dari sikap rang tua yang memberikan kebebasan kepada anak untuk melakukan apa yang diinginkan. Sebagai contoh adalah orang tua mengizinkan anaknya pulang malam dan keluar pada malam untuk nongkrong. Konsekuensi dari diterapkannya pola asuh permisif adalah anak tidak akan tahu tingkah laku yang dilakukannya sesuai dengan aturan atau tidak, karena orang tua tidak pernah menyalahkan dan membenarkan tingkah laku tersebut. Yoga dan Wiyani (2015) telah menjelaskan bahwa keputusan orang tua dalam menerapkan pola asuh haruslah dipikirkan secara matang agar generasi muda saat ini tidak terjerumus kedalam perilaku kenakalan.

Pola asuh permisif yang memberikan kebebasan, memanjakan anak, dan tidak adanya kontrol dari orang tua membuat anak cenderung melakukan perilaku negatif dan 
menyimpang. Sikap impulsif dan agresif, suka memberontak, kurang kendali diri, suka mendominasi, tidak jelas arah hidupnya, dan prestasinya rendah adalah sejumlah contoh perilaku negatif yang terbentuk. Selanjutnya sejumlah kenakalan mereka lakukan seperti melanggar aturan, berkelahi, membolos sekolah, bahkan sampai melakukan tindak kriminal. Hal itu juga digambarkan oleh Sanjiwani dan Budisetyani (2014) bahwa pola asuh permisif mendorong remaja melakukan kenakalan dan menjadikan anak semakin agresif. Penelitian Udampo, Onibala, dan Bataha (2017) juga menunjukkan bahwa pola asuh permisif mendorong terbentuknya kenakalan pada remaja. Isnasari (2014) juga menemukan adanya hubungan positif yang signifikan antara pola asuh permisif orang tua dengan kenakalan pada remaja.

Gaya pengasuhan orang tua adalah faktor terpenting dalam perkembangan psikososial anak-anak. Peran orang tua sangat diperlukan untuk mengasah kemampuan sosialisasi anak di lingkungan masyarakat serta menjaga rasa integritas pribadi. Anakanak menghabiskan sebagian besar waktu di rumah sehingga perilaku dan cara komunikasi orangtua dengan anak-anak juga berdampak pada mereka. Jika orang tua terlalu memanjakan dan kurang adanya kontrol maka akan mendorong anak memiliki kepribadian yang buruk dalam kehidupan mereka. Orangtua boleh mengkontrol anak tetapi harus konsisten agar dapat menghasilkan anak yang sehat fisik dan mental (Farzana Bibi, 2013). Sikap suportif, perhatian, dan fleksibel yang ditunjukkan orangtua dapat membentuk anak-anak yang sehat secara mental, ramah secara sosial, mandiri, dan kreatif (Baumrind, 2013).

\section{Simpulan dan Saran}

Penelitian ini menunjukan adanya korelasi positif antara pengasuhan permissive orangtua dengan perilaku kenakalan pada remaja di SMU Surabaya. Semakin permisif pengasuhan yang dilakukan orangtua maka semakin besar kemungkinan terbentuknya perilaku kenakalan pada remaja. Sekolah perlu mengidentifikasi secara dini munculnya kenakalan pada siswa mereka dan melakukan sosialisasi perilaku yang dilakukan para siswa. Jika dapat terkontrol dan terawasi diharapkan tidak sampai terjerumus ke dalam kenakalan yang lebih berat. Pola asuh lainnya dapat menjadi ide untuk penelitian selanjutnya dalam melihat isu kenakalan pada remaja yang terjadi.

\section{Daftar Pustaka}

Allen, W. D., \& Olson, D. H. (2001). Five types of African-American marriages. Journal of Marital and Family Therapy. https://doi.org/10.1111/j.1752-0606.2001.tb00326.x

Anjaswarni, T., Nursalam, N., Widati, S., \& Yusuf, A. (2019). Analysis of the Risk Factors Related to the Occurrence of Juvenile Delinquency Behavior, 14(2), 129-136.

Baumrind, D. (2013). Effective parenting during the early adolescent transition. In Family Transitions. https://doi.org/10.4324/9780203772393

Euis, S. (2004). mengasuh dengan hati. Jakarta: Elex Media Komputindo.

Farzana Bibi, F. B. (2013). Contribution of Parenting Style in life domain of Children. IOSR Journal of Humanities and Social Science, 12(2), 91-95. https://doi.org/10.9790/0837-1229195

Hurlock, E. (2014). Perkembangan Anak Edisi Keenam Jilid I. Jakarta. Penerbit Erlangga. https://doi.org/10.1078/0944-2006-00091

Isnasari, Y. (2014). Hubungan Pola Asuh Permisif Orang Tua terhadap Kenakalan Remaja di Balai Pemasyarakatan Kelas I Semarang. Fakultas Dakwah dan Komunikasi Institut Agama Islam Negeri Walisongo Semarang.

John W. Santrock. (2011). LIFE-SPAN Development (13th ed.). Jilid II. Erlangga.

Kartono. (2006). Patologi Sosial 2. Kenakalan Remaja. jakarta: Rajawali Pers. 
Muhammad, A., \& Muhammad, A. (2006). Psikologi Remaja, Perkembangan Peserta Didik. Journal of Educational Social Studies. https://doi.org/10.15294/jess.v7i1.22502

Mulyono, Y. B. (2005). Pendekatan Analisis Kenakalan Remaja dan Penanggulangannya. Yogyakarta: Kanisius.

Prihatin, Agung and, Abi Muhlisin, SKM, M. K. (2014). hubungan antara pengaruh teman sebaya dan pola asuh orang tua dengan perilaku mengkonsumsi minuman keras di Desa Cangkol Sragen. Universitas Muhammadiyah Surakarta.

Proboningrum. (2001). Psikologi perkembangan. Yogyakarta: Gadjah Mada Universuty Press.

Sanjiwani, N. L. P. Y., \& Budisetyani, I. G. A. P. W. (2014). Pola Asuh Permisif Ibu dan Perilaku Merokok Pada Remaja Laki-Laki di Sma Negeri 1 Semarapura. Jurnal Psikologi Udayana. https://doi.org/10.24843/jpu.2014.v01.i02.p13

Sarwono, S. W. (2011). Psikologi Remaja Edisi Revisi. Psikologi Remaja. https://doi.org/10.1108/09513551011032482.Bastian

Sharma, M., Sharma, N., \& Yadava, A. (2011). Parental styles and depression among adolescents. Journal of the Indian Academy of Applied Psychology.

Sudarsono. (2012). Kenakalan Remaja: Prevensi, Rehabilitasi, dan Resosialisasi. (: PT. Rineka Cipta, Ed.). Jakarta: PT. Rineka Cipta.

Sunaryanti, S. S. (2016). Relationship The Parenting Pattern And The Juvenile Delinquency At State Senior Secondary School 8 Surakarta. Indonesian Journal On Medical Science, 38-47.

Udampo, A., Onibala, F., \& Bataha, Y. (2017). HUBUNGAN POLA ASUH PERMISIF ORANG TUA DENGAN PERILAKU MENGKONSUMSI ALKOHOL PADA ANAK USIA REMAJA DI DESA BULUDE SELATAN KABUPATEN TALAUD. JURNAL KEPERAWATAN.

Wittenborn, M. (2002). The Relations Between Parenting Styles and Juvenile Delinquency. Honors Theses. Retrieved from http://www.sjsu.edu/people/francis.krebs/courses/scwk131sec02/s2/Kumpfer FAMILY strengthening - DOJ literature_review_1999.pdf\%5Cnhttp://opensiuc.lib.siu.edu/cgi/viewcontent.cgi?arti cle $=1263 \&$ context $=$ uhp_theses

Yoga, Wiyani, \& I. (2015). correlation between parenting parents with sociopathic behavior of student in tenth grade in smk bopkri 1 yogyakarta. Jurnal Keperawatan Respati, 1-11. 